\title{
Different fixative solutions in the detection of mast cells in the canine and feline reproductive organs
}

\author{
P. Hamouzova, P. Cizek, A. Bartoskova, R. Novotny \\ University of Veterinary and Pharmaceutical Sciences, Brno, Czech Republic \\ [Received: 21 May 2019; Accepted: 3 August 2019]
}

\begin{abstract}
Background: The aim of the study was to evaluate the usability of different fixative fluids in the detection of mast cells in ovaries and uteri of female dogs and cats. Materials and methods: Samples were fixed in 4\% formaldehyde, Carnoy's fluid, Mota's basic lead acetate and isotonic formaldehyde-acetic acid (IFAA).

Results: Mast cells (MCs) were detected by acidified toluidine blue staining and counted for various parts of the ovaries and uteri. In the ovaries of both species, the numbers of MCs were significantly $(p<0.05)$ higher in Carnoy than in formalin. No significant differences were found between Carnoy and Mota (tested only in cats). In the uterus, numbers of MCs were significantly $(p<0.05)$ higher in Carnoy, Mota and IFAA compared to formalin (canine endometrium, feline endometrium and feline myometrium), in Carnoy and Mota compared to formalin (canine myometrium) and in Mota compared to IFAA (feline myometrium). The majority of MCs were formalin-sensitive in the canine and feline uterus, in the canine ovary and in the feline cortex ovarii. In the feline medulla ovarii, the majority of MCs were formalin-resistant. No formalin-resistant MCs were detected in the feline tunica albuginea ovarii.

Conclusions: Thus, using Mota's or Carnoy's fluid in the canine or feline female reproductive organs is recommended. This study improves methodology for all studies which clarify the role of MCs in the reproductive organs of the domestic and laboratory animals. (Folia Morphol 2020; 79, 2: 265-271)
\end{abstract}

Key words: Carnoy, dog, formol, Mota, ovary, uterus

\section{INTRODUCTION}

The significant effect of the used fixation technique on the total number of detected mast cells (MCs) has been described [1, 17, 19, 31]. Glycosaminoglycans (responsible for metachromatic staining) contained in granules of certain MCs are soluble in water and therefore require alcohol fixation in combination with other substances for their preservation [31].

Mast cells can be classified on the basis of their sensitivity to aldehyde fixation [17]. This sensitivity is related to the content of different glycosaminoglycans $[3,18]$ or even to the amount of histamine $[8]$ in granules of MCs.

Choosing the most suitable fixative fluid is therefore essential for the optimal detection of MCs. The only study of the canine uterus compared only Carnoy's fluid and formalin [17]. The situation in cats is unknown even if these are widespread veterinary patients.

The absence of optimal method of specimen fixation for the detection of MCs significantly limits the

Address for correspondence: Dr. P. Čížek, ÚAHE VFU Brno, Palackého 1946/1, 61242 Brno, Czech Republic, tel: +420 737729863 , e-mail: cizekpetr@yahoo.com 
possibilities of research of MC function in physiological processes in the reproductive organs or their role in the pathologies. This study compares the number of MCs detected in samples fixed in several fixation fluids and describes the distribution of formalin-sensitive MCs.

As to the methods of MC detection, situation is very complicated in veterinary sciences. Although tryptase detection is known as a very reliable method for human uterine MCs [13], tryptase-negative MCs were reported in various animal species including dogs [17]. Therefore, classical histochemical staining such as toluidine blue is still widely used for detection of the total number of MCs in animals [e.g. 4, 7, 10, $21,24-26,37,38]$. Moreover, a significantly higher number of MCs was detected by thiazine dyes than by immunohistochemistry in various canine organs including uterus [17]. Because thiazine dyes are still preferred in many veterinary studies, it is necessary to improve the fixation methodology for them. Thus, the aim of this study was to find out which fixative fluids are best suited to use in studies where the total number of MCs is monitored in animals, especially in the reproductive organs. (The topic of the role of MCs in the reproductive organs was recently reviewed [28] and their possible effect on the reproductive processes is studied intensively [e.g. 6, 9-12, 15, 20-24, 27, $30,32]$. Thus, it is necessary to know the best detection techniques of MCs in the reproductive system.)

\section{MATERIALS AND METHODS}

\section{Animals}

The samples were collected from 9 healthy bitches and 12 healthy queens (sexually mature, cycling) that were kept as pets. The animals were brought to the veterinary clinic in order to be spayed. No experiment was performed, only the material from the preventive neutering was used.

\section{Tissue processing}

This study was focused on ovaries (9 canine, 12 feline) and uterine horns (9 canine, 9 feline). The obtained part of the uterine horn was equally divided into 4 fixation fluids. The ovaries were divided only into two fixative fluids (due to their size and problematic division into the equal parts). Each sample of organ was divided into parts and each part was fixed in a different fixation fluid. Three fixative fluids were used in the feline ovaries (Carnoy, Mota and formalin); two fixation fluids were used in the canine ovaries (Carnoy, formalin). Four fixation fluids were used in canine and feline uteri (Carnoy, Mota, isotonic formaldehyde acetic acid and formalin). Ovaries (especially in cats) are very small. Moreover, they are hard to cut into smaller and equal parts. Therefore, they were fixed in a smaller number of fluids than the uteri. All fixation fluids were prepared in the laboratory. Carnoy's fluid was mixed from absolute ethanol, chloroform and glacial acetic acid in proportion 6:3:1, respectively immediately before fixation. Mota's basic lead acetate (BLA) contained $1 \mathrm{~g} \mathrm{BLA}, 50 \mathrm{~mL}$ distilled water, $50 \mathrm{~mL}$ absolute ethanol and $0.5 \mathrm{~mL}$ glacial acetic acid [33-35]. Isotonic formaldehyde acetic acid (IFAA) was mixed from $1.5 \mathrm{~mL} 37 \%$ formaldehyde, $98 \mathrm{~mL}$ distilled water and $0.5 \mathrm{~mL}$ glacial acetic acid $[33,34]$. Formalin was common neutral buffered $10 \%$ formol. All fluids were stored at a room temperature.

Samples in Carnoy's fluid were fixed for $4-5 \mathrm{~h}$ and then transferred into absolute ethanol where they were fixed for another $20 \mathrm{~h}$. This technique provides a higher stability of the samples. In all other fluids, samples were fixed for $24 \mathrm{~h}$.

After the fixation had been completed, the samples from Mota, formalin or IFAA were dehydrated in graded ethanol series (the ethanol concentration in each subsequent bath was increased by $10 \%$ ), acetone, and three baths of xylene. At the end of dehydration process, samples were infiltrated with hot paraffin and embedded in paraffin wax. Then, 3-4 $\mu \mathrm{m}$ thin sections were cut in the routine manner. The sections were deparaffinised and stained with acidified toluidine blue $(0.5 \%$ solution in $0.25 \mathrm{M}$ $\mathrm{HCl}$ ). The staining time was $15 \mathrm{~min}$. The toluidine blue powder was T3260; Sigma-Aldrich.

The dehydration in graded ethanol series was omitted in the Carnoy's fluid fixed samples because this fixative was prepared from anhydrous reagents. These samples were only immersed in xylene after the fixation and subsequently processed identically to the other samples.

A single paraffin block was made from each sample of each fixation fluid. Three sections were taken from each block and evaluated under an Olympus BX 51 light microscope at $400 \times$ magnification.

In the ovary, MCs were counted separately in the cortical stroma (ovarian follicles and corpora lutea were excluded) and in the medulla. In the uterus, MCs were counted separately in the endometrium and myometrium. Results are expressed as the number of MCs per $1 \mathrm{~mm}^{2}$. 
Table 1. Effect of the fixation fluid on the number of mast cells $/ \mathrm{mm}^{2}$ in the ovary

\begin{tabular}{lcccc}
\hline Animal & Part of organ & Fluid & Mean \pm SD & $\begin{array}{c}\text { Median } \\
\text { (min-max) }\end{array}$ \\
\hline Bitch & Cortex ovarii & Carnoy & $10.6 \pm 7.9$ & $8(3-27)$ \\
Bitch & Cortex ovarii & Formalin & $1.4 \pm 1.8$ & $1(0-5)$ \\
Bitch & Medulla ovarii & Carnoy & $21.3 \pm 10.7$ & $19(8-38)$ \\
Bitch & Medulla ovarii & Formalin & $4.1 \pm 2.7$ & $4(1-10)$ \\
Cat & Cortex ovarii & Carnoy & $19.0 \pm 11.61$ & $18.5(7-34)$ \\
Cat & Cortex ovarii & Formalin & $2.7 \pm 1.63$ & $2.5(1-5)$ \\
Cat & Cortex ovarii & Carnoy & $33.5 \pm 34.84$ & $26.5(4-91)$ \\
Cat & Cortex ovarii & Mota & $30.7 \pm 27.12$ & $28(4-68)$ \\
Cat & Medulla ovarii & Carnoy & $20.8 \pm 8.54$ & $20.5(9-33)$ \\
Cat & Medulla ovarii & Formalin & $12.2 \pm 3.43$ & $12.5(7-16)$ \\
Cat & Medulla ovarii & Carnoy & $24.8 \pm 15.94$ & $21(10-49)$ \\
Cat & Medulla ovarii & Mota & $28.7 \pm 19.15$ & $25.5(11-53)$ \\
Cat & Tunica albuginea & Carnoy & $11.5 \pm 5.54$ & $9.5(6-21)$ \\
Cat & Tunica albuginea & Formalin & $0.0 \pm 0.00$ & $0(0-0)$ \\
Cat & Tunica albuginea & Carnoy & $7.8 \pm 3.71$ & $7(4-14)$ \\
Cat & Tunica albuginea & Mota & $11.7 \pm 5.85$ & $11(6-21)$ \\
\hline
\end{tabular}

SD — standard deviation. Samples of ovaries from each cat were fixed in Carnoy and Mota or in Carnoy and formalin. For this reason, formalin and Mota cannot be compared (pair samples of ovaries fixed in formalin and Mota were not available).

\section{Statistical analysis}

Results were statistically evaluated by the ANOVA method of analysis of variance. The differences between mean values were evaluated (after a previous error analysis and evaluation of the influential values) by the Tukey HSD test in the SAS computer programme (SAS Institute, Carry, USA), version 9.4 at the level of significance $p=0.05$ (mean, standard deviation and median described in tables are based on section mean per animal).

\section{RESULTS}

\section{Ovary}

In all parts of the ovary, the numbers of MCs were significantly $(p<0.05)$ higher in Carnoy than in formalin in both species. No significant differences were found between Carnoy and Mota (tested only in cats), $p>0.05$. More detailed results are described in Table 1. The distribution of MCs in the canine and feline ovaries can be seen in Figures 1-6.

\section{Uterus}

In the uterus, the numbers of MCs were significantly $(p<0.05)$ higher in Carnoy, Mota and IFAA

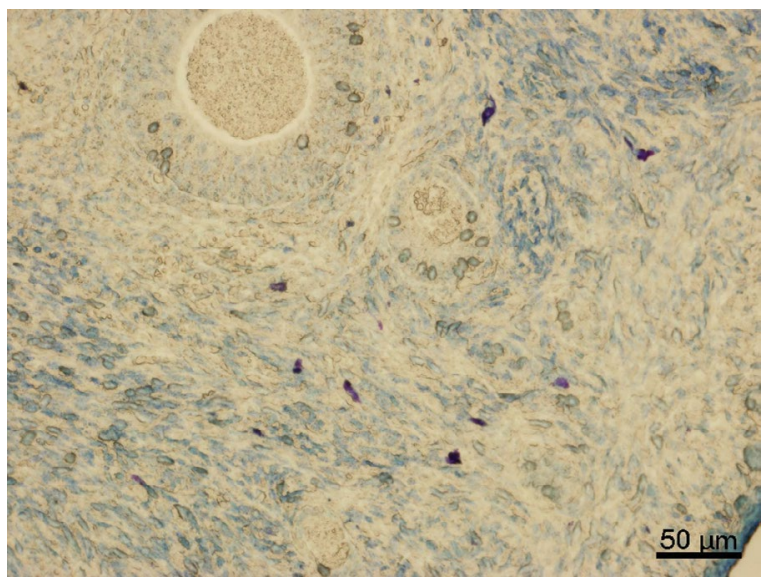

Figure 1. Canine ovary, cortex, Carnoy. The dyeability of mast cells (MCs) granules is distinctive. Significantly increased number of detected MCs compared to formalin (Fig. 2).

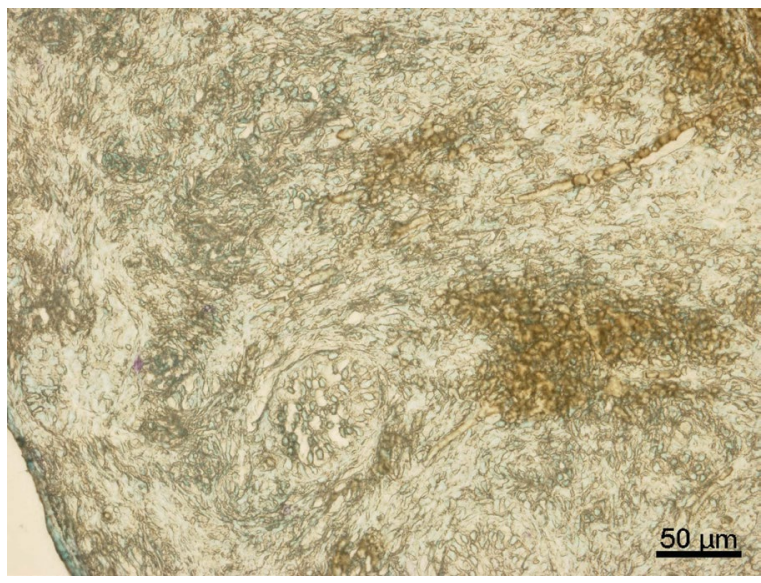

Figure 2. Canine ovary, cortex, formalin. In detected mast cells (MCs), the dyeability of granules is weaker compared to Carnoy (Fig. 1). Significantly decreased number of MCs compared to Carnoy (Fig. 1).

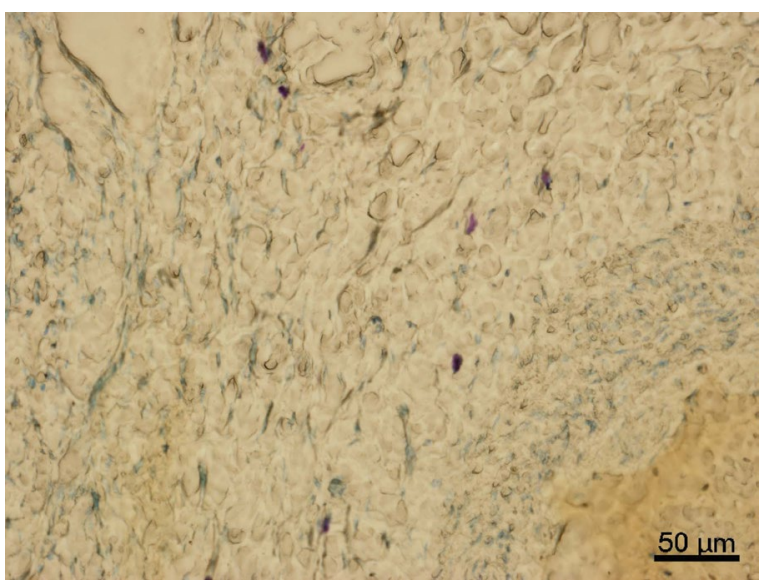

Figure 3. Canine ovary, medulla, Carnoy. Significantly increased number of mast cells compared to formalin (Fig. 4). 


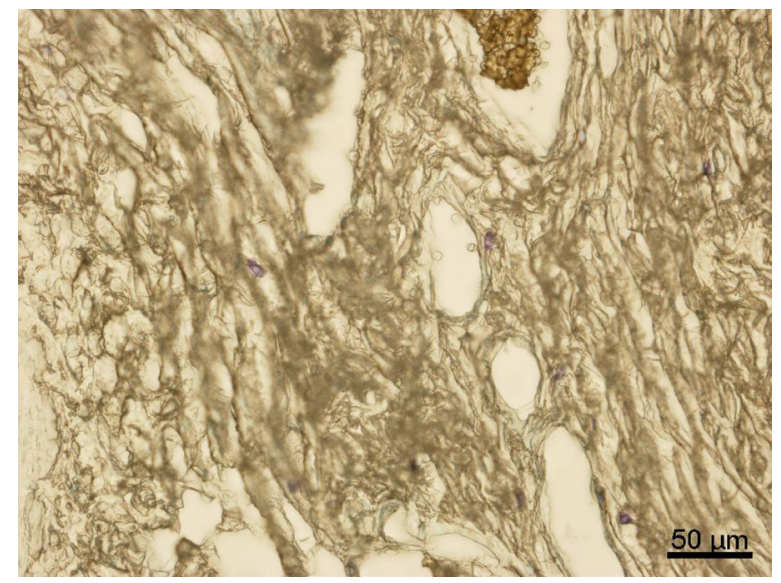

Figure 4. Canine ovary, medulla, formalin. In detected mast cells (MCs), the dyeability of MC granules is weaker compared to Carnoy (Fig. 3). Significantly decreased number of MCs compared to Carnoy (Fig. 3).

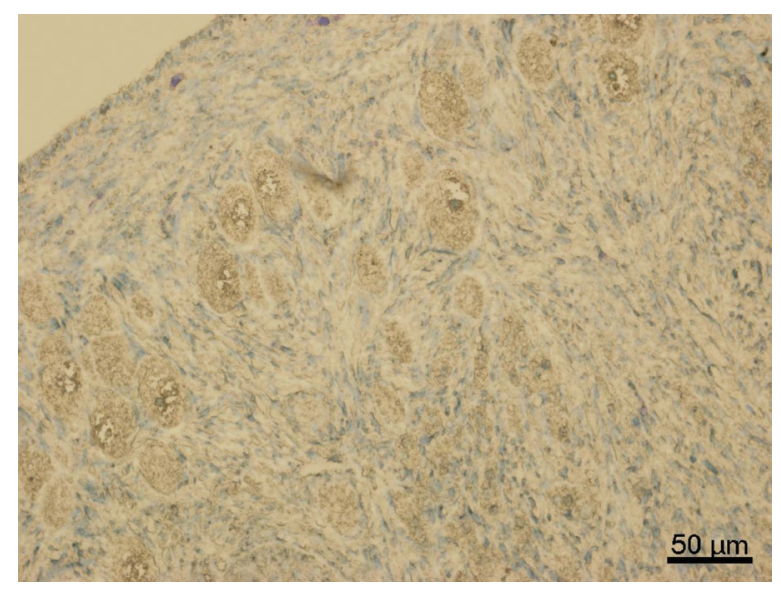

Figure 5. Feline ovary, tunica albuginea, Carnoy. No significant difference in the number of mast cells, dyeability of granules or in intensity of the background tissue compared to Mota (Fig. 6).

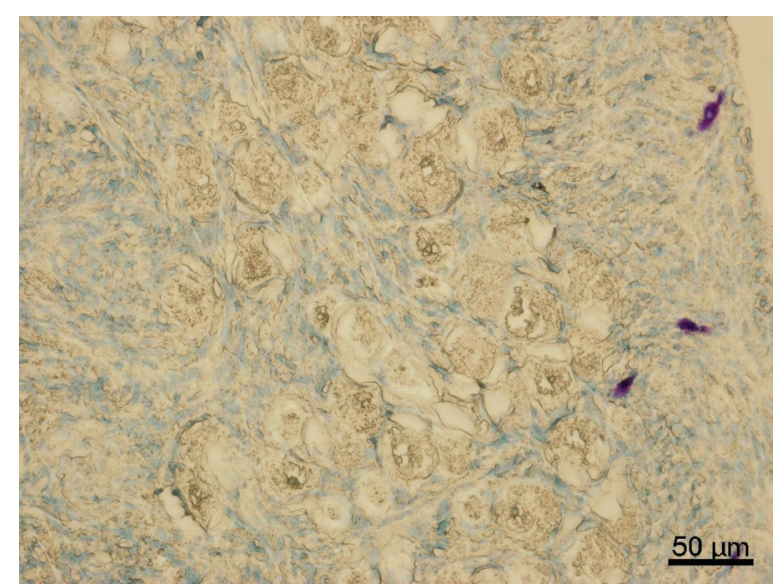

Figure 6. Feline ovary, tunica albuginea, Mota. No significant difference compared to Carnoy (Fig. 5).
Table 2. Effect of the fixation fluid on the number of mast cells $/ \mathrm{mm}^{2}$ in the uterus

\begin{tabular}{lcccc}
\hline Animal & Part of organ & Fluid & Mean \pm SD & $\begin{array}{c}\text { Median } \\
\text { (min-max) }\end{array}$ \\
\hline Bitch & Endometrium & Carnoy & $41.9 \pm 37.35$ & $32(5-131)$ \\
Bitch & Endometrium & Formalin & $7.7 \pm 6.73$ & $7(0-22)$ \\
Bitch & Endometrium & IFAA & $38.7 \pm 36.89$ & $39(2-125)$ \\
Bitch & Endometrium & Mota & $39.1 \pm 34.58$ & $31(6-119)$ \\
Bitch & Myometrium & Carnoy & $52 \pm 26.59$ & $53(18-94)$ \\
Bitch & Myometrium & Formalin & $20.2 \pm 17.28$ & $16(1-48)$ \\
Bitch & Myometrium & IFAA & $39.2 \pm 23.04$ & $33(13-78)$ \\
Bitch & Myometrium & Mota & $55 \pm 32.57$ & $39(23-115)$ \\
Cat & Endometrium & Carnoy & $11.9 \pm 10.53$ & $9(2-34)$ \\
Cat & Endometrium & Formalin & $0.9 \pm 1.05$ & $1(0-3)$ \\
Cat & Endometrium & IFAA & $9.7 \pm 9.99$ & $8(0-30)$ \\
Cat & Endometrium & Mota & $13.9 \pm 11.37$ & $9(2-35)$ \\
Cat & Myometrium & Carnoy & $30.9 \pm 19.31$ & $31(11-70)$ \\
Cat & Myometrium & Formalin & $2.9 \pm 2.15$ & $3(0-6)$ \\
Cat & Myometrium & IFAA & $19.9 \pm 13.05$ & $20(3-41)$ \\
Cat & Myometrium & Mota & $40.4 \pm 25.86$ & $31(11-81)$ \\
\hline
\end{tabular}

IFFA — isotonic formaldehyde-acetic; SD — standard deviation

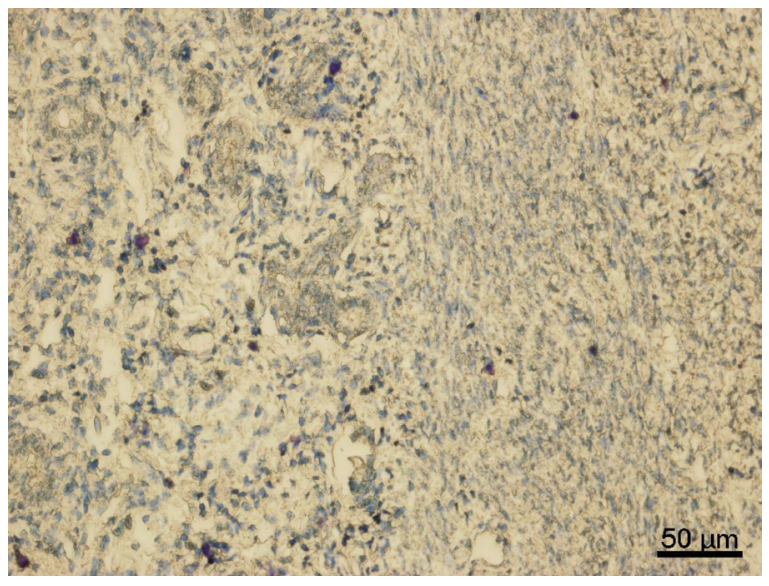

Figure 7. Canine uterus, Carnoy. Significantly increased number of mast cells compared to formalin (Fig. 8). The background tissue is highly stained in Carnoy but not in other fluids (see Fig. 8, 9, 10 for comparison).

compared to formalin (canine endometrium, feline endometrium and feline myometrium), in Carnoy and Mota compared to formalin (canine myometrium) and in Mota compared to IFAA (feline myometrium). Other differences were not significant $(p>0.05)$. More detailed results are described in Table 2 . The distribution of MCs in the canine uteri can be seen in Figures 7-10. 


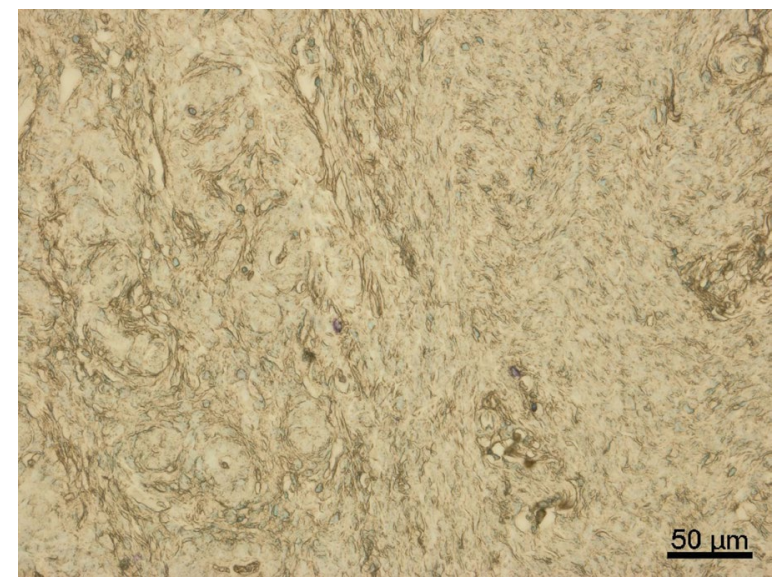

Figure 8. Canine uterus, formalin. In detected mast cells (MCs), the dyeability of MC granules is weaker compared to Carnoy (Fig. 7) or Mota (Fig. 10), but similar compared to isotonic formaldehyde-acetic acid (IFAA) (Fig. 9). Significantly decreased number of MCs compared to Carnoy (Fig. 7), IFAA (Fig. 9) and Mota (Fig. 10) was detected.

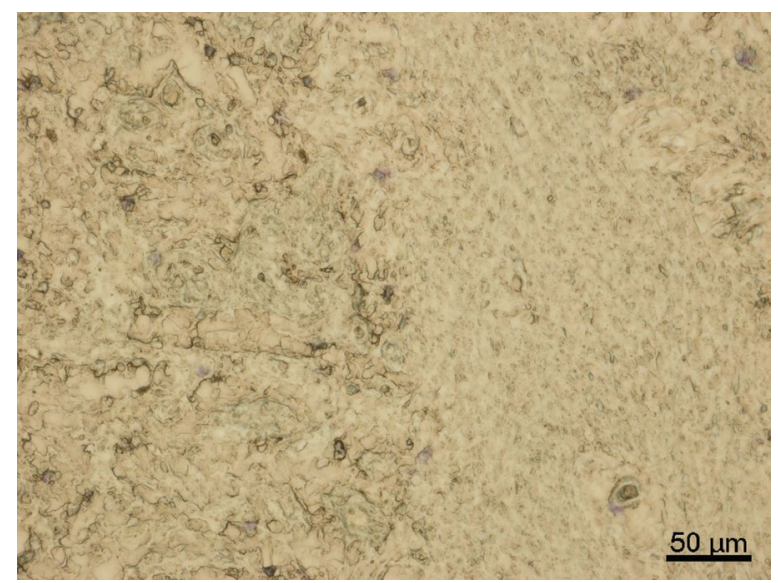

Figure 9. Canine uterus, isotonic formaldehyde-acetic acid. The weak dyeability of granules is similar compared to formalin (Fig. 8). In the endometrium (left half of the figure), the number of mast cells was significantly increased compared to formalin (Fig. 8).

\section{Sensitivity to formalin}

The percentage of formalin-sensitive MCs with respect to the number of MCs detected after the fixation in Carnoy's fluid was determined. No formalin-resistant MCs were detected in the feline tunica albuginea ovarii. In other parts of assessed organs, the percentage of formalin-sensitive MCs fluctuates from $37.8 \pm 12.9 \%$ in the feline medulla ovarii to $90.4 \pm 11.4$ in the feline endometrium. The majority of MCs were formalin-sensitive in the canine and feline uterus, in the canine ovary and in the feline cortex ovarii. However, in the feline medulla ovarii, the majority of MCs were formalin-resistant. More detailed results are described in Table 3.

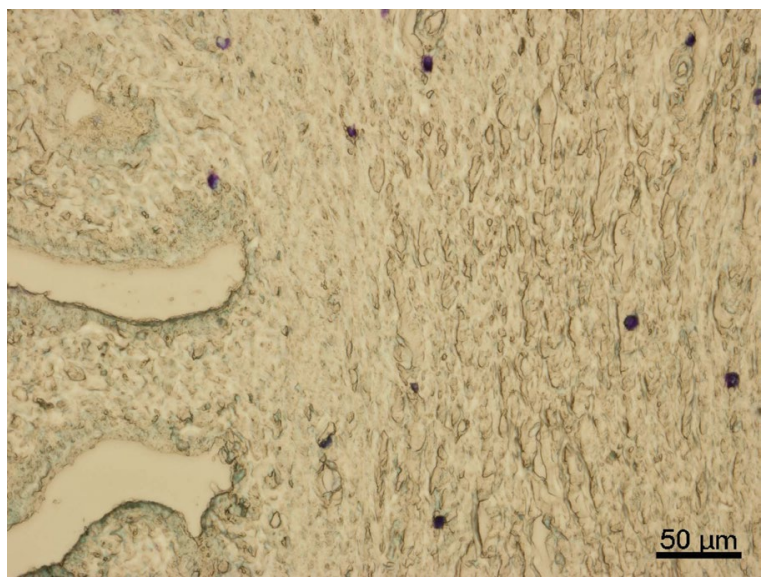

Figure 10. Canine uterus, Mota. The dyebility of granules is as distinctive as in Carnoy and surrounding tissue is less stained compared to Carnoy (Fig. 7). Significantly increased number of detected mast cells compared to formalin (Fig. 8).

Table 3. Percentage of formalin-sensitive mast cells in the ovary and uterus (compared to Carnoy's fluid)

\begin{tabular}{lccc}
\hline Animal & Part of organ & $\begin{array}{c}\text { Mean } \pm \text { SD } \\
{[\%]}\end{array}$ & $\begin{array}{c}\text { Median (min-max) } \\
{[\%]}\end{array}$ \\
\hline Bitch & Cortex ovarii & $89.4 \pm 12.1$ & $87.5(66.7-100)$ \\
Bitch & Medulla ovarii & $76.8 \pm 18.7$ & $84.2(41.2-92.6)$ \\
Cat & Cortex ovarii & $76.8 \pm 27.8$ & $92.7(28.6-95.8)$ \\
Cat & Medulla ovarii & $37.8 \pm 12.9$ & $37.7(22.2-57.6)$ \\
Cat & Tunica albuginea & $100.0 \pm 0.0$ & $100(100-100)$ \\
Bitch & Endometrium & $74.4 \pm 22.5$ & $75.9(31.2-93.9)$ \\
Bitch & Myometrium & $62.4 \pm 28.8$ & $69.8(11.1-95.6)$ \\
Cat & Endometrium & $90.4 \pm 11.4$ & $97(75-100)$ \\
Cat & Myometrium & $85 \pm 11.6$ & $80.6(72.7-100)$ \\
\hline
\end{tabular}

$\mathrm{SD}$ - standard deviation

\section{DISCUSSION}

In all examined organs, significant differences in the total number of MCs between individual animals were found. Kube et al. [17] also described significant differences between individuals in the canine uterus. In our opinion, the reason could have been the use of material from animals in different stages of the oestrous cycle. The effect of the phase of the oestrous cycle on the number of MCs has been described in both species $[7,9,10]$. Nevertheless, the differences among the individual animals were not so important for this study because the only changed and monitored parameter in each tested organ was the fixation fluid used.

We found that Carnoy's fluid and Mota's BLA were equally applicable in all parts of the canine and 
feline ovaries, whereas fixation in formalin showed that the number of formalin-sensitive MCs was high in the ovaries of both species so fixation in formalin cannot be recommended.

Based on these results, Carnoy's fluid and Mota's BLA are equally applicable in all parts of the canine and feline uterus. IFAA can be reliably used in all parts of the feline uterus and in the canine endometrium but gave lower numbers of detected MCs in the canine myometrium.

The majority of MCs were formalin-sensitive in all evaluated areas of the organs except the feline medulla ovarii. Kube et al. [17] also found formalin-sensitive MCs in the canine uterus but the majority of MCs were formalin-resistant. Changes in the percentage of formalin-sensitive/resistant MCs described in some diseases [36] show that the percentage of formalin-sensitive/resistant MCs depends on the local environment of the organ. Therefore we expect that changes in the sex hormone levels during the oestrous cycle may affect the ratio of formalin-resistant and formalin-sensitive MCs. This could be the reason why the proportion of formalin-sensitive MCs varies in our study compared to Kube et al. [17].

It was proposed that MCs play a role in the process of ovulation in cats [10]. During the ovulation, the tunica albuginea is ruptured so we decided to focus on this area in cats. All MCs in this location were formalin-sensitive. We expect that they belong to one biological subtype which plays a major role in the process of feline ovulation. Further investigation should be provided.

It has been reported that all mucosal MCs in rodents are formalin-sensitive [5]. However, both types as to the fixability by aldehydes were described in the mucosa [e.g. 1, 2, 16, 18] in the majority of species including the dog [1]. Our results confirm this fact both types of MCs were found in the endometrium.

Based on the results, fixation in IFAA was reliably applicable for detection of MCs in the canine uterus and feline endometrium. However, the total number of MCs was significantly lower in IFAA compared to Mota's BLA in the feline myometrium. This corresponds to a significantly higher number of MCs in IFAA fixed samples compared to formalin reported in the canine skin [2] and in the ovine uterine tube [18].

Carnoy's fluid is widely used for the fixation of MCs in genital organs [e.g. 16, 17, 19] due to the good results of this method. Mota's BLA was used for the fixation of reproductive organs in several studies [14-16]. Nevertheless, none of these studies described the efficiency of Mota versus other fixation techniques so the appropriateness of this method has been verified only by this study. Our results showed that the numbers of MCs were at their highest after fixation in Carnoy (or Mota) in both organs of both studied species.

To conclude, the results prove the significant effect of the fixation fluid on the total number of detected MCs. This effect should be always taken into account. Since there were no significant differences in comparison with other studies, we would not be afraid to apply the basic results to other organs or domestic animal species.

\section{CONCLUSIONS}

It follows from our results that the use of Carnoy and Mota was reliable in all examined organs.

Thus, we recommend using Mota's BLA or Carnoy's fluid for performing studies focused on the detection of MCs in the female reproductive organs of domestic carnivores. Studies of the role of MCs in the reproductive processes should be performed in optimally fixed samples. The results of the current study offer this solution. The conclusion of this study is useful for studies describing the total number of MCs in domestic as well as laboratory animals.

\section{REFERENCES}

1. Al-Zghoul MB, Al-Rukibat RK, Alghadi M, et al. Distribution and density of mast cells in camel small intestine and influence of fixation techniques. Eur J Histochem. 2008; 52(4): 237-241, doi: 10.4081/1222, indexed in Pubmed: 19109098.

2. Asti RN, Kurtdede A, Kurtdede N, et al. Mast cells in the dog skin: distribution, heterogeneity and influence of the fixation techniques. Ankara Univ Vet Fak Derg. 2005; 52: 7-12.

3. Broome M, Villarreal B. Differential staining of mast cells with toluidine blue. J Histotechnol. 2012; 35(1): 27-30, doi: 10.1179/2046023611y.0000000006.

4. Dong $H$, Wang $Y$, Zhang $X$, et al. Stabilization of brain mast cells alleviates LPS-induced neuroinflammation by inhibiting microglia activation. Front Cell Neurosci. 2019; 13: 191, doi: 10.3389/fncel.2019.00191, indexed in Pubmed: 31130850.

5. Enerbäck L. Mast cells in rat gastrointestinal mucosa. I. Effects of fixation. Acta Pathol Microbiol Scand. 1966; 66(3): 289-302, doi: 10.1111/apm.1966.66.3.289, indexed in Pubmed: 4162017.

6. Garfield RE, Irani AM, Schwartz LB, et al. Structural and functional comparison of mast cells in the pregnant versus nonpregnant human uterus. Am J Obstet Gynecol. 2006; 194(1): 261-267, doi: 10.1016/j.ajog.2005.05.011, indexed in Pubmed: 16389041.

7. Goericke-Pesch S, Schmidt B, Failing K, et al. Changes in the histomorphology of the canine cervix through the oestrous cycle. Theriogenology. 2010; 74(6): 1075-1081, 1081e1, doi: 10.1016/j.theriogenology.2010.05.004, indexed in Pubmed: 20580071. 
8. Gurish MF, Austen KF. Developmental origin and functional specialization of mast cell subsets. Immunity. 2012; 37(1): 25-33, doi: 10.1016/j.immuni.2012.07.003, indexed in Pubmed: 22840841.

9. Hamouzova P, Cizek P, Bartoskova A, et al. Influence of oestradiol and progesterone levels on the number of mast cells in the feline myometrium. In: Cerkal R, Brezinova Belcredi N, Prokesova L, editors:MendelNet 2017. Proceedings of 24th International PhD Students Conference. Mendel University in Brno, Brno. 2017: 691-695.

10. Hamouzova P, Cizek P, Novotny R, et al. Distribution of mast cells in the feline ovary in various phases of the oestrous cycle. Reprod Domest Anim. 2017; 52(3): 483-486, doi: 10.1111/rda.12938, indexed in Pubmed: 28211113.

11. Ivanisevic M, Segerer S, Rieger L, et al. Antigen-presenting cells in pregnant and non-pregnant human myometrium. Am J Reprod Immunol. 2010; 64(3): 188-196, doi: 10.1111/j.1600-0897.2010.00858.x, indexed in Pubmed: 20528834.

12. Jensen F, Woudwyk M, Teles A, et al. Estradiol and progesterone regulate the migration of mast cells from the periphery to the uterus and induce their maturation and degranulation. PLoS One. 2010; 5(12): e14409, doi: 10.1371/ journal.pone.0014409, indexed in Pubmed: 21203555.

13. Jeziorska M, Salamonsen L, Woolley D. Mast cell and eosinophil distribution and activation in human endometrium throughout the menstrual cycle1. Biol Reprod. 1995; 53(2): 312-320, doi: 10.1095/biolreprod53.2.312, indexed in Pubmed: 7492683.

14. Karaca $\mathrm{T}$, Arikan $\mathrm{S}$, Kalender $\mathrm{H}$, et al. Distribution and heterogeneity of mast cells in female reproductive tract and ovary on different days of the oestrus cycle in Angora goats. Reprod Domest Anim. 2008; 43(4): 451-456, doi: 10.1111/j.1439-0531.2007.00934.x, indexed in Pubmed: 18298406.

15. Karaca T, Yörük M, Uslu S. Distribution and quantitative patterns of mast cells in ovary and uterus of rat. Arch Med Vet. 2007; 39(2): 135-139, doi: 10.4067/s0301$732 \times 2007000200006$

16. Karaca T, Yörük M, Uslu S, et al. Distribution of eosinophil granulocytes and mast cells in the reproductive tract of female goats in the preimplantation phase. Vet Res Commun. 2009; 33(6): 545-554, doi: 10.1007/s11259009-9203-x, indexed in Pubmed: 19184632.

17. Kube $P$, Audigé $L, K u ̈ t h e r ~ K$, et al. Bovine mast cells: distribution, density, heterogeneity, and influence of fixation techniques. Cell Tissue Res. 1998; 293(1): 111-119, doi: 10.1007/s004410051103, indexed in Pubmed: 9634603 .

18. Kürüm A, Özen A, Karahan S, et al. Investigation of mast cell distribution in the ovine oviduct during oestral and luteal phases of the oestrous cycles. Kafkas Univ Vet Fak Derg. 2014; 20: 915-920.

19. Küther $K$, Audigé $L$, Kube $P$, et al. Bovine mast cells: distribution, density, heterogeneity, and influence of fixation techniques. Cell Tissue Res. 1998; 293(1): 111-119, doi: 10.1007/s004410051103, indexed in Pubmed: 9634603.

20. Lee SKi, Kim CJ, Kim DJ, et al. Immune cells in the female reproductive tract. Immune Netw. 2015; 15(1): 16-26, doi: 10.4110/in.2015.15.1.16, indexed in $\mathrm{Pu}$ bmed: 25713505.

21. Li Y, Yang T, Yao Q, et al. Metformin prevents colonic barrier dysfunction by inhibiting mast cell activation in maternal separation-induced IBS-like rats. Neurogastroenterol Motil. 2019; 31(5): e13556, doi: 10.1111/nmo.13556, indexed in Pubmed: 30740845

22. Lychkova $A E$, De Pasquale $V$, Avallone $L$, et al. Serotonin regulates contractile activity of the uterus in non-pregnant rabbits. Comp Biochem Physiol C Toxicol Pharmacol. 2014; 165: 53-59, doi: 10.1016/j.cbpc.2014.05.006, indexed in Pubmed: 24892885.

23. Menzies FM, Higgins CA, Shepherd MC, et al. Mast cells reside in myometrium and cervix, but are dispensable in mice for successful pregnancy and labor. Immunol Cell Biol. 2012; 90(3): 321-329, doi: 10.1038/icb.2011.40, indexed in Pubmed: 21577230.

24. Meyer N, Santamaria CG, Müller JE, et al. Exposure to 17 -ethinyl estradiol during early pregnancy affects fetal growth and survival in mice. Environ Pollut. 2019; 251: 493-501, doi: 10.1016/j.envpol.2019.04.144, indexed in Pubmed: 31103009.

25. Meyer N, Woidacki K, Knöfler M, et al. Chymase-producing cells of the innate immune system are required for decidual vascular remodeling and fetal growth. Sci Rep. 2017; 7: 45106, doi: 10.1038/srep45106, indexed in Pubmed: 28327604.

26. Meyer N, Woidacki K, Maurer M, et al. Safeguarding of fetal growth by mast cells and natural killer cells: deficiency of one is counterbalanced by the other. Front Immunol. 2017; 8: 711, doi: 10.3389/fimmu.2017.00711, indexed in Pubmed: 28670317.

27. Meyer N, Schüler T, Zenclussen AC. Simultaneous ablation of uterine natural killer cells and uterine mast cells in mice leads to poor vascularization and abnormal doppler measurements that compromise fetal well-being. Front Immunol. 2018; 8: 1913, doi: 10.3389/fimmu.2017.01913, indexed in Pubmed: 29375562.

28. Meyer N, Zenclussen AC. Mast cells: good guys with a bad image? Am J Reprod Immunol. 2018; 80(4): e13002, doi: 10.1111/aji.13002, indexed in Pubmed: 29917288.

29. Needham K, Fadia M, Dahlstrom JE, et al. Significance of mast cell distribution in placental tissue and membranes in spontaneous preterm birth. J Inflamm Res. 2016; 9: 141-145, doi: 10.2147/JIR.S80722, indexed in Pubmed: 27468246.

30. Ozen A, Ergun L, Ergun E, et al. Morphological studies on ovarian mast cells in the cow. Turk J VetAnim Sci. 2007; 31: 131-136.

31. Rieger J, Twardziok S, Huenigen $\mathrm{H}$, et al. Porcine intestinal mast cells. Evaluation of different fixatives for histochemical staining techniques considering tissue shrinkage. Eur J Histochem. 2013; 57(3): e21, doi: 10.4081/ejh.2013.e21, indexed in Pubmed: 24085270.

32. Salamonsen LA, Jeziorska M, Newlands GF, et al. Evidence against a significant role for mast cells in blastocyst implantation in the rat and mouse. Reprod Fertil Dev. 1996; 8(8): 1157-1164, doi: 10.1071/rd9961157, indexed in Pubmed: 8981640.

33. Strobel S, Miller HR, Ferguson A. Human intestinal mucosal mast cells: evaluation of fixation and staining techniques. J Clin Pathol. 1981; 34(8): 851-858, doi: 10.1136/ jcp.34.8.851, indexed in Pubmed: 6168659.

34. Uslu S, Yörük M. Morfological and histometric studies on mast cell distribution and heterogeneity, present in the lower respiratory tract and in the lung of local duck (anas platyrhnchase) and goose (anser anser). Kafkas Univ Vet Fak Derg. 2013, doi: 10.9775/kvfd.2012.8064.

35. Uslu SS, Yörük M. A morphological and histometric study on the distribution and heterogeneity of mast cells found in lungs and trachea of Van Cats. Ankara Univ Vet Fak Derg. 2015; 62(2): 87-91, doi: 10.1501/ vetfak_0000002663.

36. Walls $\bar{A}$, Roberts JA, Godfrey RC, et al. Histochemical heterogeneity of human mast cells: disease-related differences in mast cell subsets recovered by bronchoalveolar lavage. Int Arch Allergy Appl Immunol. 1990; 92(3): 233-241, doi: 10.1159/000235183, indexed in Pubmed: 1703515.

37. Woidacki K, Popovic M, Metz $M$, et al. Mast cells rescue implantation defects caused by c-kit deficiency. Cell Death Dis. 2013; 4: e462, doi: 10.1038/cddis.2012.214, indexed in Pubmed: 23328669.

38. Woidacki K, Meyer N, Schumacher A, et al. Transfer of regulatory $T$ cells into abortion-prone mice promotes the expansion of uterine mast cells and normalizes early pregnancy angiogenesis. Sci Rep. 2015; 5: 13938, doi: 10.1038/ srep13938, indexed in Pubmed: 26355667. 